\title{
Computer-aided measurement of geometric parameters of the deformation zone in the burnishing process
}

\section{ANDRZEJ ZABORSKI *}

Dr hab. inż. Andrzej Zaborski, prof. PCz, zaborski@itm.pcz.czest.pl, https://orcid.org/0000-0003-1738-5034 - Politechnika Częstochowska, Instytut Technologii Mechanicznych, Częstochowa, Polska

The paper discusses the possibility of using computer technology for determining the spatial shape and stereometry of the burnishing tool contact zone with the machined material. The potential for use of the integrated measurement stand for the comprehensive analysis and virtual visualization of variations in the shape of burnished cylindrical surfaces based on stereometry measurement using a profilographometer (New Form Talysurf 2D/3D 120 by Taylor Hobson) and subsequent roundness measurements (Talyrond 365 by Taylor Hobson) has been presented. KEYWORDS: surface stereometry measurements, burnishing working

\section{Introduction}

Surface treatment with burnishing involves the use of local plastic deformation in the surface layer of the object as a result of contact interaction of the tool (in the shape of a ball, disc, roller, etc.) with the machined surface $[3,6]$. During burnishing at sufficiently high pressures, the flow of material can lead to the formation of a wave of stacked material in front of the burnishing surface on the machined surface - both in the axial and circumferential direction. The area of formed unevenness has a complicated, three-dimensional shape [4-6]. The paper presents description of changes occurring in the spatial shape of deformation zones at various burnishing technological parameters.

\section{Studies upon contact zone stereometry}

Contact zone stereometry was measured on a New Form Talysurf 2D/3D 120 profilograph by Taylor Hobson with Ultra Surface 5.16 and TalyMap Platinium 5.1.1 software for comprehensive measurements of surface roughness and stereometry parameters in 2D and 3D with a measuring head resolution of $3.2 \mathrm{~nm}[1,2]$. The software allows to make measurements necessary for three-dimensional reproduction of the shape of uneven formation zone, generated during the tool contact with the workpiece (C55 steel). During burnishing, surface unevenness (remaining after previous machining) is permanently deformed, and a new roughness structure is created on the machined surface, conditioned by burnishing kinematics - with intervals between the tops of inequality close to the burnishing feedrate [7, 8]. A wave of deformed material moves in front of the tool (fig. 1). 


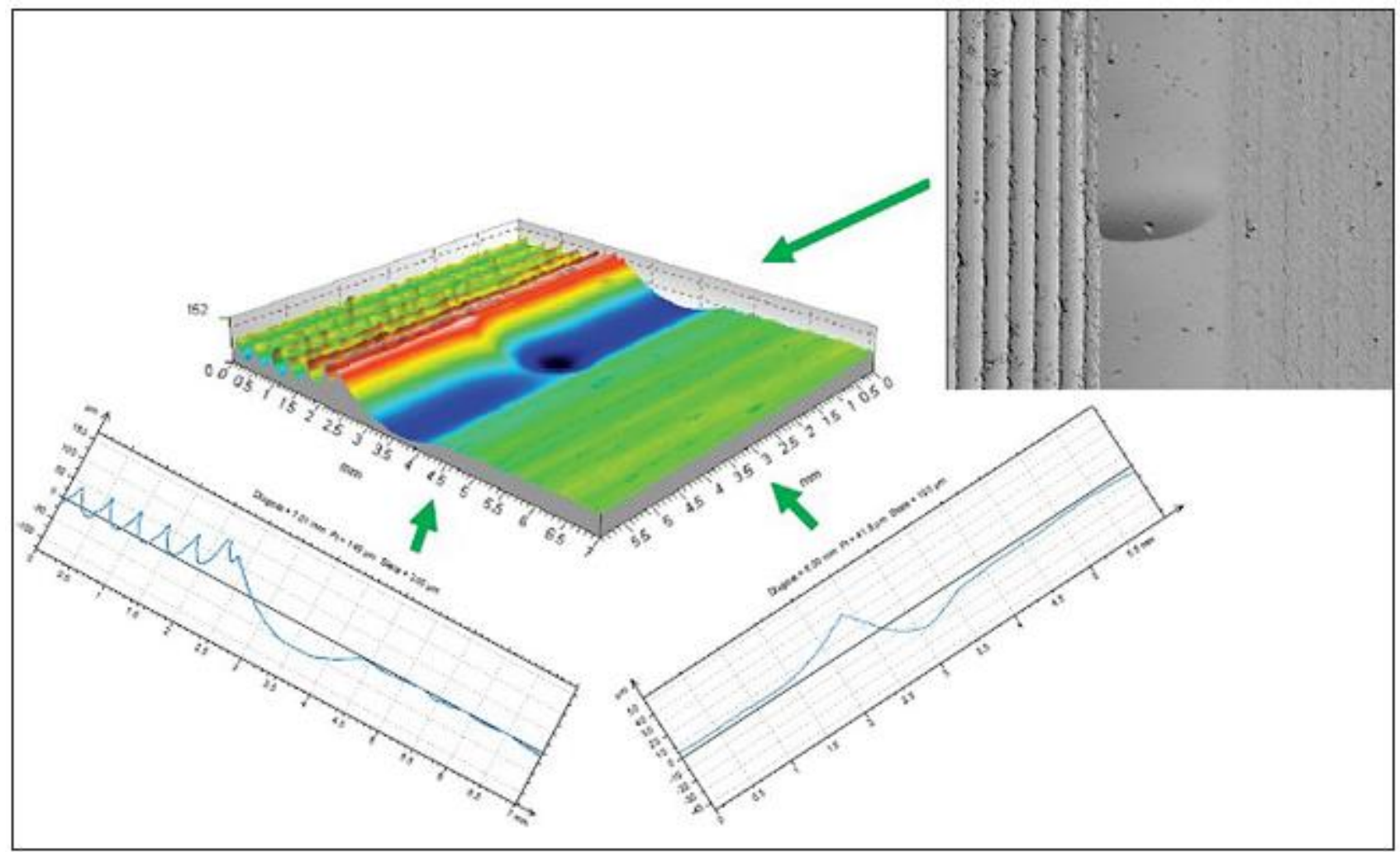

Fig. 1. Stereometric image of the contact zone of the burnishing tool with the surface burnished with a ball $R=5 \mathrm{~mm}$; burnishing force $F=2.75 \mathrm{kN}$, feedrate $f_{\text {tocz }}=0.410 \mathrm{~mm} / \mathrm{rev}$, feedrate $f_{\text {nagn }}=0.102$ $\mathrm{mm} / \mathrm{rev}$ (area after turning: $S z=91.7 \mu \mathrm{m}, S a=18.9 \mu \mathrm{m}$; area after burnishing $S z=21,2 \mu \mathrm{m}, S a=2.4$ $\mu \mathrm{m})$

The most important for describing the burnishing process is the analysis of phenomena occurring during the formation of unevenness in the place of momentary contact of the tool with the material. Deformation zone has a complicated, three-dimensional shape with characteristic material waves, running in the axial and circumferential direction (in a direction perpendicular and parallel to the direction of the main machining movement). Two waves of piled up, deformed material form on the surface of the material - one in the circumferential direction and the other in the axial direction. Unevenness after previous machining is permanently deformed.

The actual shape of the analyzed area presented in figs. 1 and 2 is a fragment of the lateral surface of the burnished cylinder. The drawings also show cross-sections of the deformation zone determined in parallel and perpendicular directions to the feed direction. The three-dimensional image of recorded deformation zone (after initial digital processing consisting in its leveling and rejecting unnecessary fragments of the examined area) also allows for a full spatial analysis of geometrical parameters adopted to describe the obtained images of the deformation zone (fig. 2). 


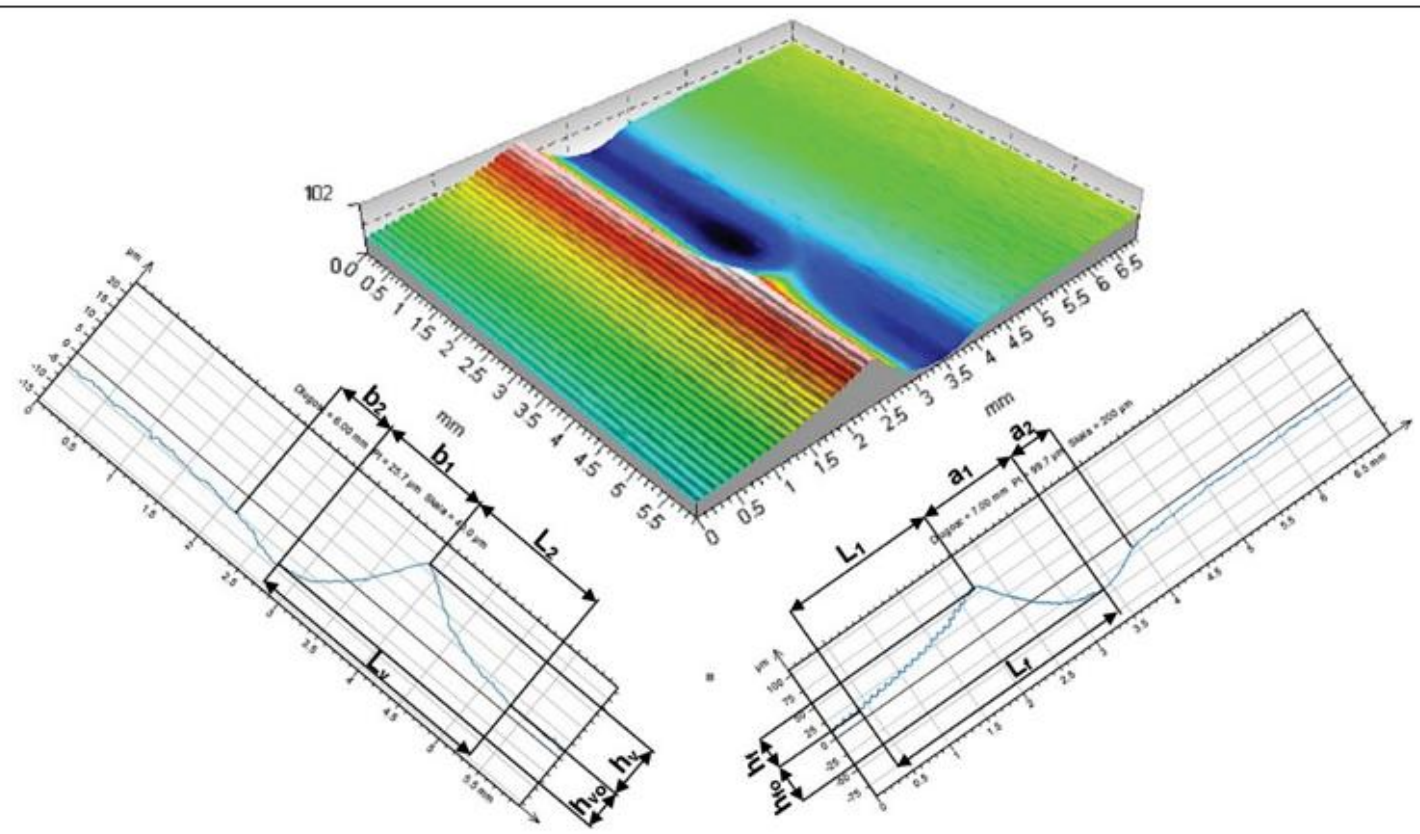

Fig. 2. Parameters of the deformation focus geometry

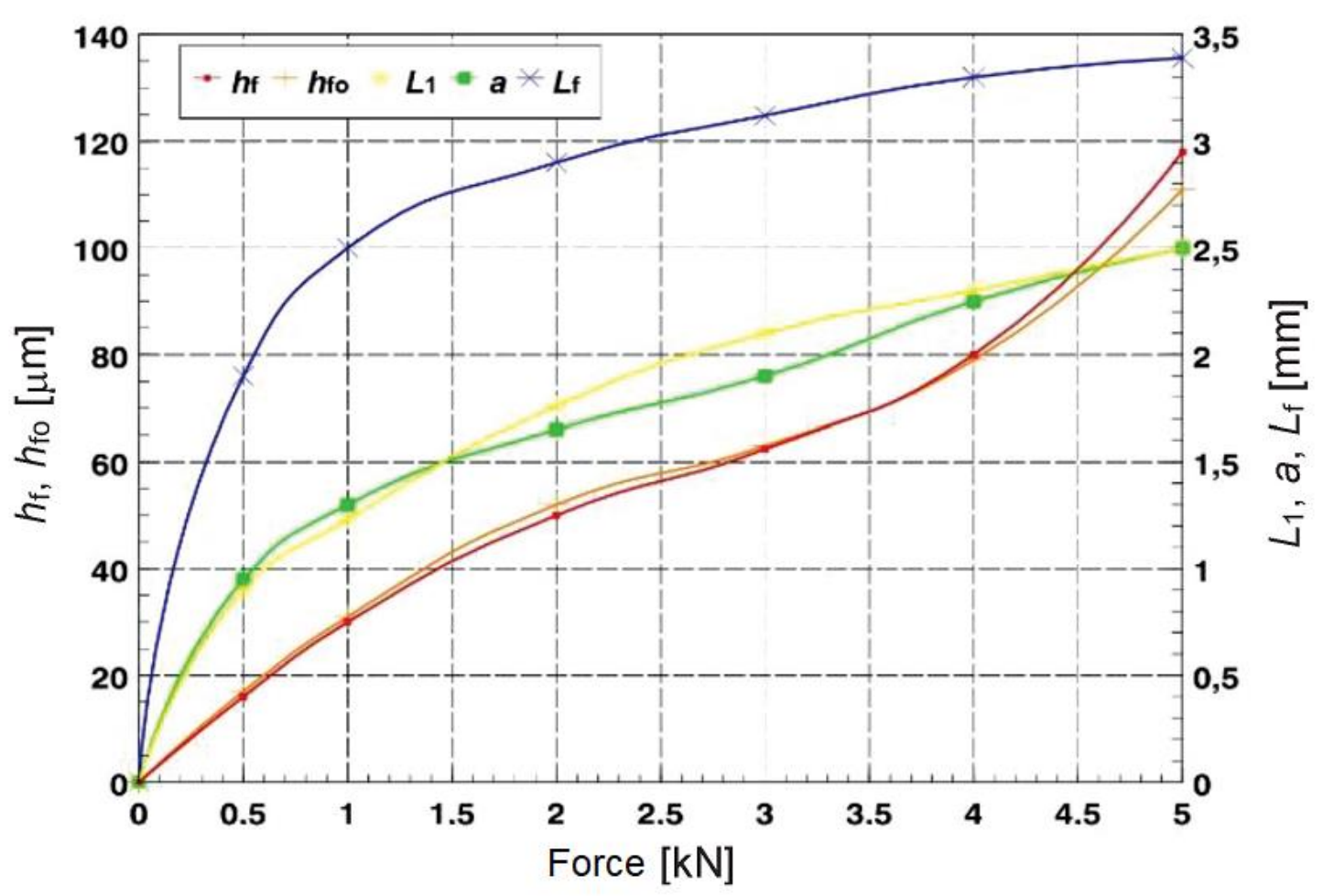

Fig. 3. Example of the influence of burnishing force on the change of some parameters of the focus of deformation during burnishing with a ball with a radius $R=5 \mathrm{~mm}(f=0.102 \mathrm{~mm} / \mathrm{rev})$, determined in the axial section $\left(h_{f}, h_{f o}, L_{1}, a, L_{f}\right)$

The tests measured geometrical parameters describing the focus of deformation in the axial section (in the feed plane: $h_{f}, h_{f o}, L_{1}, a=a_{1}+a_{2}, L_{f}$ ) and in the peripheral plane (main movement plane: $h_{v}, h_{v o}, L_{2}, b=b_{1}+b_{2}$, $L_{v}$ ). The analysis of parameters in the peripheral cross-section has a complementary meaning. Measurements indicate that during rolling burnishing with the use of a ball, the greatest impact on the increase in dimensions and depth of the deformation zone being formed was exerted primarily by value of the tool pressure force (fig. $3)$.

The course of changes in geometric parameters also depended on the radius of the burnishing tool. For surfaces burnished with tools with larger radii, the transition from a type I deformation focus (characteristic for small unit pressures) to a type II and III deformation focus requires the use of significantly higher burnishing forces. The impact of increasing burnishing feedrate is not so clear. Conducted analyses allowed to 
determine the impact of variability of the most important technological parameters (feedrate, burnishing force) on changes of geometrical parameters of the deformation zone during ball burnishing (fig. 4).

a)

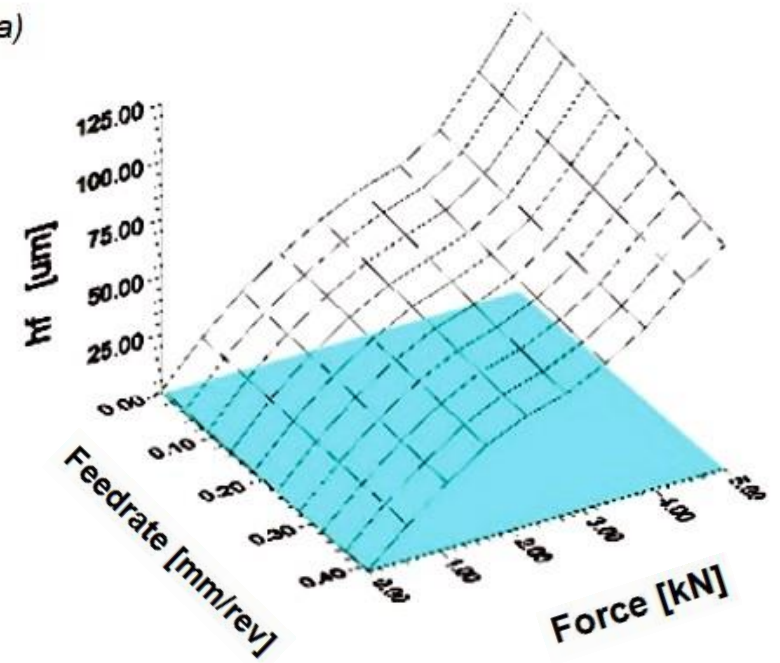

b)

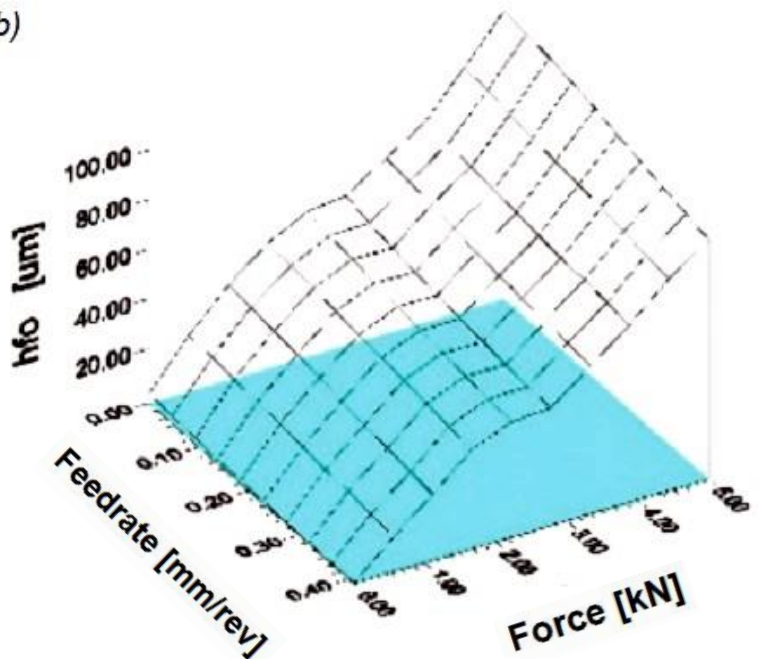

Fig. 4. Dimensions of the axial and circumferential wave of material depending on the parameters of the ball burnishing process $(R=5 \mathrm{~mm}):$ a) $h_{f}$, b) $h_{f o}$

Similar analyses were made for roller thrust burnishing processes. In this case, the dimensions of the deformation zone formed were primarily determined by the burnishing force [6, 7].

From the point of view of conducted research, it is especially important to determine the exact size of the contact surface of the tool with material (fig. 5). The analyses conducted so far indicate that in the case of burnishing elements (balls and discs), the actual contact surface is not an ellipse, as is most commonly used in theoretical process analyses. Determining the actual contact surface of the burnishing element with the workpiece has been very difficult so far, but now it is possible to solve this problem, because the use of the latest computer technology allows for precise determination of the contact zone parameters.

Due to digital processing of the obtained image of the deformation zone, it is also possible to extract any fragment from it. For example, one can digitally cut only the actual contact area of the burnishing tool with the workpiece and digitally discard material lying outside the actual contact zone. This facilitates the analysis of phenomena occurring in the correct contact zone (fig. 6).

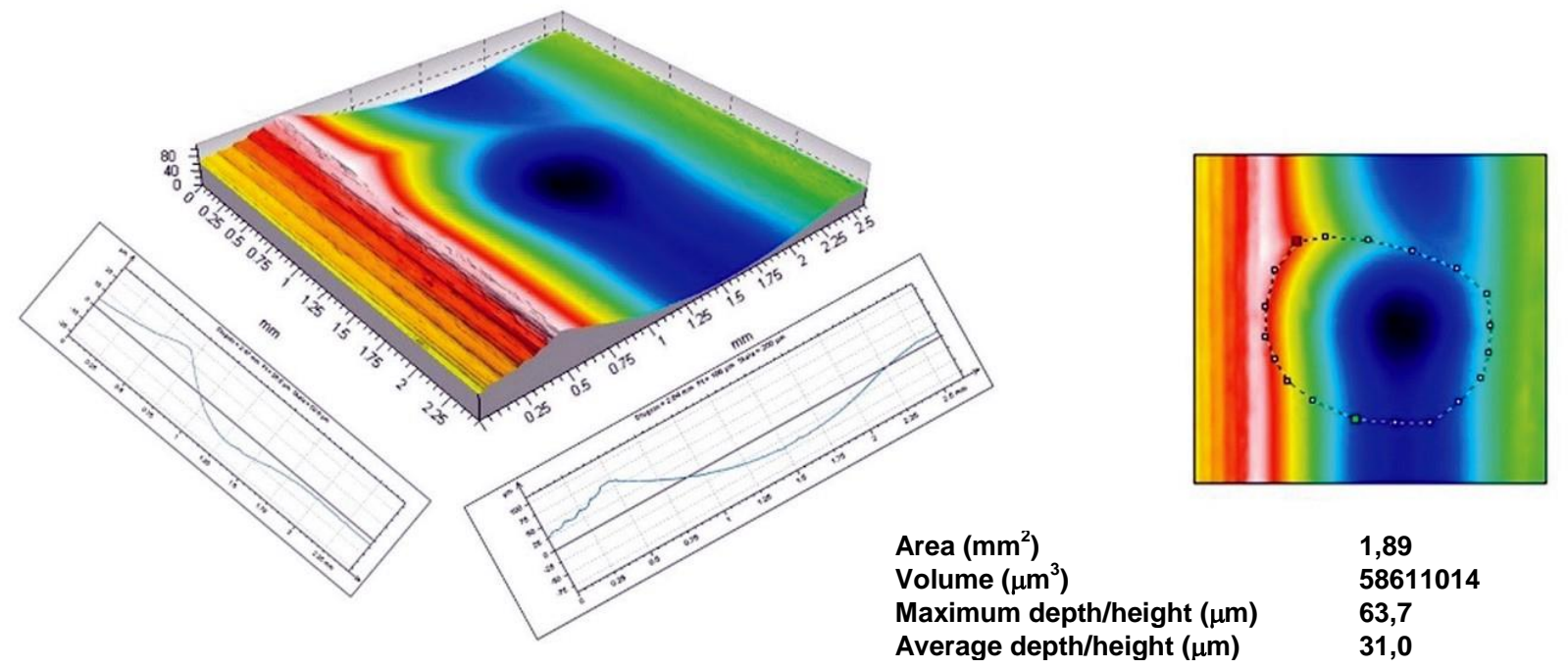

Fig. 5. Example analysis of the tool contact area with burnished material - ball burnishing $(R=5 \mathrm{~mm}, F$ $=2.75 \mathrm{kN}, f=0.068 \mathrm{~mm} / \mathrm{rev}$ ) 


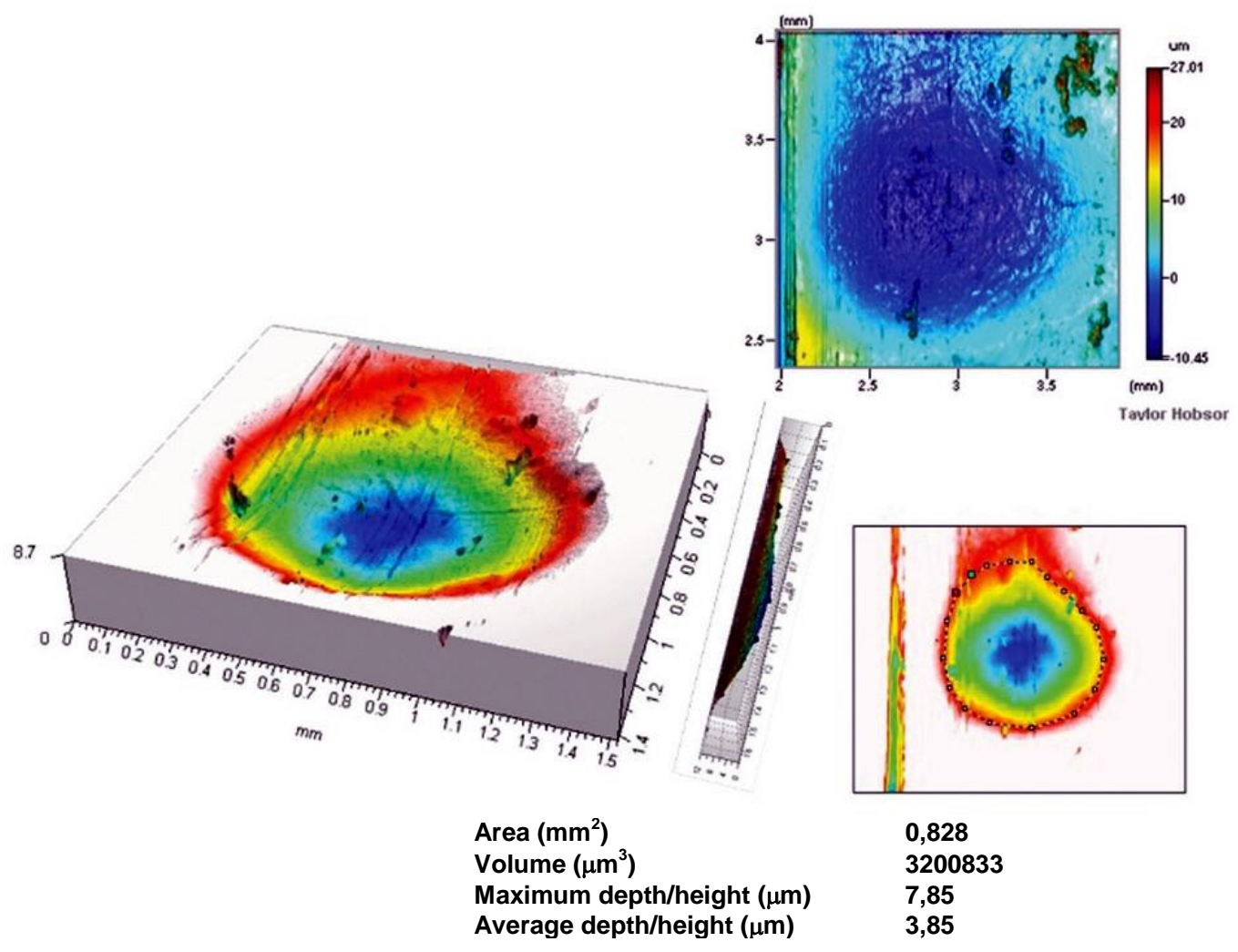

Fig. 6. Analysis of digitally processed area of contact of the tool with burnished material - roller burnishing $R k=10 \mathrm{~mm}, F=2.5 \mathrm{kN}$

\section{Spatial analysis of the deformation area shape}

Analysis of the spatial shape of the deformation area was performed on the Talyrond 365 measuring stand with the Ultra Roundness 5.17 software. Implementation of a series of roundness contours in parallel measuring planes shifted relative to each other by a given step allows to recreate the three-dimensional shape of the burnishing zone for the full circumference of the analyzed cylindrical surfaces (fig. 7).

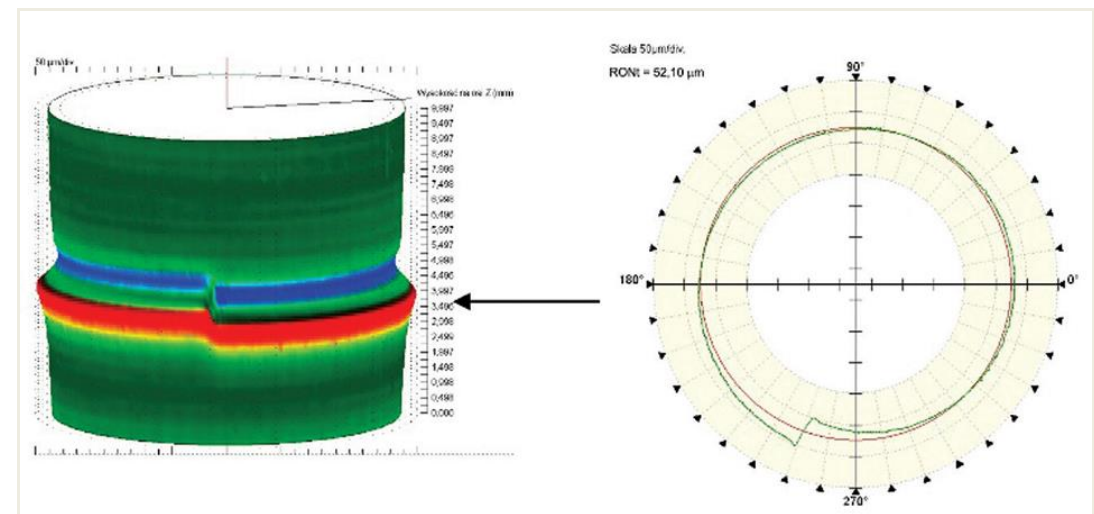

Fig. 7. Three-dimensional image of the burnishing zone of the ball burnished surface $(R=5 \mathrm{~mm}, F=$ $2.75 \mathrm{kN}, f=0.41 \mathrm{~mm} / \mathrm{rev}$ )

\section{Analysis of contact zone stereometry using a digital microscope}

Stereometry testing of the deformation zone was supplemented by the analysis of microscopic photographs illustrating changes occurring on the surface of the processed material (fig. 8). The VMHT MOT laboratory digital microscope was used. The oriented geometric structure formed as a result of turning, the oriented geometric structure obtained as a result of the cutting tool transition, is replaced by the geometric structure formed as a result of plastic deformation caused by the transition of the burnishing tool. A very clear material 
boundary is visible in the processing initiation zone (deformation zone boundary). This is the area of strong plastic deformation that begins the process of forming this zone. In the area of the deformation zone, located under the burnishing tool, traces of deformation of the plastically deformed material are revealed, with intervals resulting from the feed of the previous machining (turning).

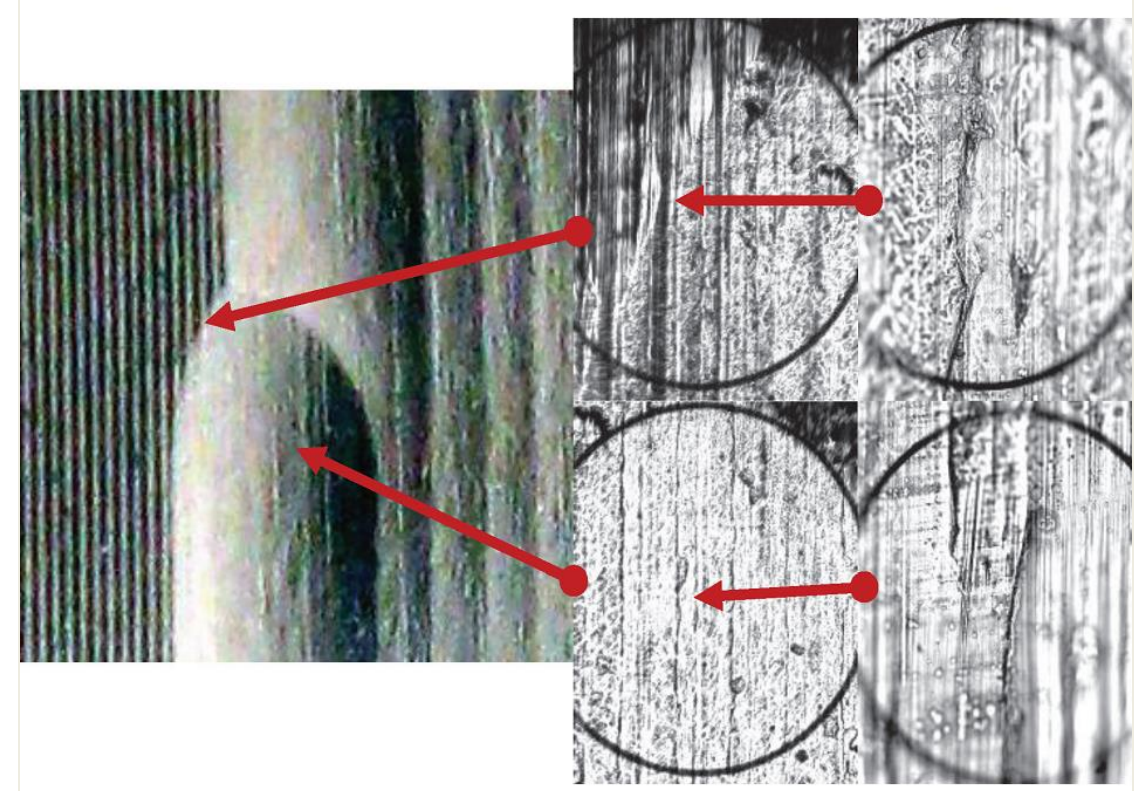

Fig. 8. Analysis of the krążek burnishing zone $(R k=5 \mathrm{~mm}, F=2.75 \mathrm{kN}, f=0.41 \mathrm{~mm} / \mathrm{rev})$ magnification $30 \times, 100 \times$ and $500 \times$

\section{Summary}

The tests carried out have shown that geometrical parameters of the deformation foci are affected by the conditions associated with the material machined and the surface roughness parameters before machining, as well as the shape of the burnishing tool and technological parameters of the burnishing process carried out.

It can be stated that from the point of view of the final effects of the analyzed process, the material flow in the axial direction, determining the final stereometry obtained as a result of machining, is of decisive importance. In addition, it has been shown that the parameters that best describe the nature of changes in the deformation zone geometry are the height of deformation wave $\left(h_{f}\right)$ determined in the plane of the axial section and the amount of the tool cavity relative to the surface of the raw material $\left(h_{f o}\right)$.

In the course of analyses, it is possible to precisely determine the contact area of the burnishing tool with the workpiece and thus to determine the actual contact stress in the contact zone.

\section{REFERENCES}

[1] Adamczak S. „Pomiary geometryczne powierzchni, zarysy kształtu, falistości i chropowatości”. WNT. Warszawa 2008.

[2] Oczoś K, Liubimov V. „Struktura geometryczna powierzchni”. Wydawnictwo Politechniki Rzeszowskiej. Rzeszów 2003.

[3] Przybylski W. „Technologia obróbki nagniataniem”. WNT, Warszawa 1987.

[4] Zaborski A. „Komputerowa analiza procesu formowania nierówności powierzchni uzyskanych na drodze obróbki nagniataniem". Mechanik 7/2011 str. 622 (streszczenie - pełny tekst na CD).

[5] Zaborski A. „Komputerowa analiza procesu formowania strefy deformacji w trakcie nagniatania”. Mechanik 7/2012 str. 607 (streszczenie - pełny tekst na CD).

[6] Zaborski A. „Analiza formowania strefy deformacji w procesie nagniatania”. Wydawnictwo Politechniki Częstochowskiej Seria Monografie nr 260. Częstochowa 2013. 